Abstracta Iranica Iranica

Revue bibliographique pour le domaine irano-aryen

Volume 32-33 | 2013

Comptes rendus des publications de 2009-2010

\title{
Rika Gyselen. Romans and Sasanians in the Third Century: Propaganda warfare and ambiguous imagery
}

\author{
Jullien Cuny
}

\section{OpenEdition}

1 Journals

Édition électronique

URL : http://journals.openedition.org/abstractairanica/40504

DOI : 10.4000/abstractairanica.40504

ISSN : 1961-960X

\section{Éditeur :}

CNRS (UMR 7528 Mondes iraniens et indiens), Éditions de l'IFRI

\section{Édition imprimée}

Date de publication : 1 décembre 2013

ISSN : 0240-8910

\section{Référence électronique}

Jullien Cuny, «Rika Gyselen. Romans and Sasanians in the Third Century: Propaganda warfare and ambiguous imagery », Abstracta Iranica [En ligne], Volume 32-33 | 2013, document 162, mis en ligne le 01 juillet 2016, consulté le 04 octobre 2020. URL : http://journals.openedition.org/abstractairanica/ 40504 ; DOI : https://doi.org/10.4000/abstractairanica.40504

Ce document a été généré automatiquement le 4 octobre 2020.

Tous droits réservés 


\title{
Rika Gyselen. Romans and Sasanians in the Third Century: Propaganda warfare and ambiguous imagery
}

\author{
Jullien Cuny
}

\section{RÉFÉRENCE}

Rika Gyselen. « Romans and Sasanians in the Third Century: Propaganda warfare and ambiguous imagery ", in : H. Börm, J. Wiesehöfer, eds., Commutation et Contention. Studies in the Late Roman, Sasanian, and Early Islamic Near East in Memory of Zeev Rubin. Düsseldorf, Wellem Verlag, 2010, p. 71-87.

1 L'A. suggère que les Sassanides au $\mathrm{III}^{\mathrm{e}} \mathrm{s}$. ont pu utiliser volontairement des motifs iconographiques ambivalents, compréhensibles par les Romains autant que par les Iraniens. Pour ce faire, ils se seraient inspirés du monnayage romain des régions frontalières, notamment de l'atelier de Samosate après la prise de la ville par Shapur $\mathrm{I}^{\mathrm{er}}$.

\section{AUTEURS}

\section{JULLIEN CUNY}

Conservateur du patrimoine, Lille 